\title{
Section IV: Unmanned Maritime Systems
}

To a certain extent, this Section overlaps some provisions of chapter "Section III: Remote and Autonomous Weapons" inasmuch as both Sections deal with unmanned systems. However, whereas chapter "Section III: Remote and Autonomous Weapons" addresses both unmanned platforms and weapon systems, the present Section focuses on unmanned maritime platforms that may or may not be integral parts of a weapon system. The maritime platforms and systems dealt with here must therefore be distinguished from automated weapon systems, in particular those for the defence of surface platforms against missile threats. Accordingly, the terminology used in this Section does not necessarily replicate that used in chapter "Section III: Remote and Autonomous Weapons".

Rule 46

(a) "Unmanned Maritime Systems" (UMS) are:

i. self-propelled or remotely-navigated craft that are normally recoverable and designed to perform functions at sea by operating on the surface, semi-submerged or undersea; and

ii. either:
a. are remotely operated,
b. are remotely controlled, or
c. perform their functions independently from a human controller or operator on board the craft.

\section{Commentary}

1. UMS comprise surface, semi-submersible and undersea vehicles of various sizes. They are either remotely operated/controlled or "autonomous". Many of the systems in use today are remotely operated or controlled but they "capitalize on automation in extreme circumstances, such as a lost link condition, to perform automatically a pre-programmed set of instructions." At present, there is no 
maritime system which may be considered as fully autonomous as defined in Rule 38.

2. UMS can perform a wide variety of missions or tasks. It is important to bear in mind that UMS, in particular Unmanned Underwater Vehicles (UUVs), are today used for the performance of the following important civilian/non-military tasks:
a. Offshore oil and gas missions;
b. Undersea cable deployment and inspection;
c. Commercial salvage;
d. Aquaculture; and
e. Science missions, such as oceanography and marine archaeology.

3. According to the DoD Roadmap, current military missions performed by UMS, i.e. Unmanned Surface Vehicles (USVs) and UUVs, include "mine warfare, mine neutralization, reconnaissance, surveillance, hydrographic surveying, environmental analysis, special operations, and oceanographic research". Similarly, the UUV Master Plan identifies nine specific mission categories and prioritizes them as follows:

a. Intelligence, surveillance, and reconnaissance (ISR);

b. Mine countermeasures (MCM);

c. Anti-submarine Warfare (ASW);

d. Inspection/identification;

e. Oceanography;

f. Communication/navigation network node $\left(\mathrm{CN}^{3}\right)$;

g. Payload delivery;

h. Information operations (IO); and

i. Time-critical strike (TCS).

4. Although it is still possible to distinguish between remotely operated and autonomous maritime vehicles, certain vehicles may have technological capabilities to be operated either by remote control or autonomously.

\section{(b) UMS include Unmanned Surface Vehicles (USVs) and Unmanned Underwater Vehicles (UUVs).}

\section{Commentary}

1. According to the US DoD, "UMS comprise unmanned maritime vehicles (UMVs), which include both unmanned surface vehicles (USVs) and unmanned undersea vehicles (UUVs), all necessary support components, and the fully integrated sensors and payloads necessary to accomplish the required missions". ${ }^{1}$

\footnotetext{
${ }^{1}$ U.S. Department of Defense, Unmanned Systems Integrated Roadmap FY2013-2038 (DoD Roadmap), page 8.
} 
Although those definitions seem to suggest that UMVs/USVs are but components of UMS, it would not be correct to hold that UMVs/USVs do not qualify as "systems" because they are composed of various subsystems. ${ }^{2}$

2. While some Governments presently prefer the use of the term "UMV", the Group of Experts took note of the fact that there is not yet a sufficiently agreed upon understanding of the various concepts. Although it is possible that all UMVs will be considered "vessels" or "ships", State practice has not yet crystallized. Since a distinction between "systems" and "vehicles" does not prove helpful, it seems appropriate, for the purposes of this Manual, to consider the terms "UMS" and "UMV" as synonymous.

\section{Rule 47}

If owned or operated by a State and used only on Government non-commercial service, all UMS enjoy sovereign immunity. This is without prejudice to their status under LOAC.

\section{Commentary}

1. The language of this Rule is based on Article 96 of the United Nations Convention on the Law of the Sea (UNCLOS). ${ }^{3}$

2. Nevertheless, although UMS navigate at sea, it is not clear whether they can be considered ships. The international law of the sea lacks a uniform definition of the term "ship". UNCLOS uses the terms "vessel" and "ship" interchangeably, without providing a definition of either term. Other relevant treaties provide varying definitions that are functionally limited. While those treaties generally do not prohibit treating UMS as vessels or ships, a number of the relevant rules were created specifically with manned systems in mind. In view of these difficulties, UMS are in some contexts not characterized as ships or vessels but rather as "craft". It is quite possible that a considerable number of States are not prepared to recognize UMS as ships/vessels, although more may be known about State views in the coming years given efforts at the International Maritime Organization (IMO) to assimilate unmanned craft to vessels/ships.

3. If UMS are operated by the armed forces or any other Government agency of a State, they may not necessarily qualify as warships or State ships. However, since they either constitute State property or used only on Government non-commercial service,

\footnotetext{
${ }^{2}$ For example, the major UUV's subsystems are: the pressure hull, the hydrodynamic hull, ballasting, power and energy, electrical-power distribution, propulsion, navigation and positioning, obstacle avoidance, masts, manoeuvre control, communications, locator and emergency equipment, payloads. See National Defense Research Institute, A Survey of Missions for Unmanned Undersea Vehicles (RAND) (2009), page $46 \mathrm{ff}$.

${ }^{3}$ United Nations Convention on the Law of the Sea of 10 December (UNCLOS) (1982), UNTS, vol. 1833, page 397.

${ }^{4}$ U.S. Navy/U.S. Marine Corps/U.S. Coast Guard, The Commander's Handbook on the Law of Naval Operations (NWP 1-14M), paras. 2.3.4-2.3.6 (Edition July 2007).
} 
they do enjoy sovereign immunity. Hence, they may only be interfered with by other States in very exceptional circumstances (e.g., in an international armed conflict). Accordingly, "USVs and UUVs engaged exclusively in Government, non-commercial service are sovereign immune craft.",

4. It is important to note that an independent legal status of sovereign immunity applies to UMS operating independently from another platform. Therefore, "USV/UUV status is not dependent on the status of its launch platform." ${ }^{\prime \prime}$ If the UMS is tethered to a controlling platform, it is difficult to attach to it an independent legal status.

5. This Rule is without prejudice to the belligerent right of sinking warships and other lawful targets in armed conflict.

\section{Rule 48}

In peacetime, UMS enjoy all navigational rights in accordance with the international law of the sea, i.e. innocent passage in territorial sea areas, transit passage in international straits, archipelagic sea lanes passage and freedom of navigation in the high seas and in the Exclusive Economic Zone (EEZ).

\section{Commentary}

1. USVs and UUVs retain the same independent rights of navigation as manned surface vessels and submarines. States in general have not (as yet) made statements to that effect, although they make use of UMS for governmental, scientific and commercial purposes. Hence, it is safe to conclude that UMS enjoy the right of freedom of navigation in the high seas and in the EEZ as well as the rights of innocent passage, transit passage and archipelagic sea lanes passage.

\section{Rule 49}

With respect to an armed conflict, States bear responsibility for internationally wrongful operations using UMS that are attributable to them. Such responsibility encompasses actions by all persons belonging to the armed forces.

\section{Commentary}

1. For an interpretation of this Rule, see the commentaries on Rules 5, 21 and 43.

\section{Rule 50}

All those involved in the conduct of operations, including attacks, using UMS, are responsible for their respective roles and, commensurate with

\footnotetext{
${ }^{5} N W P$ 1-14M, see fn. 4, para. 2.3.6.

${ }^{6}$ Ibid.
} 
their involvement, have obligations to ensure that such operations are conducted in accordance with the applicable principles and rules of LOAC.

\section{Commentary}

1. See Commentaries on Rules 5, 22 and 44.

\section{Rule 51}

A person who wrests control of a UMS or its weapons, assumes responsibility for its subsequent use in accordance with the degree and duration of the control exercised.

\section{Commentary}

1. See the Commentaries on Rules 6 and 45.

\section{Rule 52}

During an armed conflict, UMS may be employed for attacks and for the exercise of other belligerent rights if they:

(a) are operated by the armed forces of a State;

\section{Commentary}

1. Although it is unsettled whether UMS qualify as, or are assimilated to, warships, State practice seems to suggest that they are, and will be, used not only for attack purposes but also for the exercise of other belligerent rights, such as inspection of vessels.

(b) bear the military markings of that State; and

\section{Commentary}

1. Since the exercise of belligerent rights will predominantly occur in high seas areas, there is a need for transparency because not only enemy vessels may be affected but also neutral vessels. Therefore, in times of international armed conflict, UMS should be identifiable as belonging to the armed forces of a Belligerent State.

(c) are controlled or deployed by persons subject to regular armed forces discipline.

\section{Commentary}

1. Those controlling or deploying UMS should be under regular armed forces discipline in order to ensure compliance with LOAC. The fact that the software on the UMS has been programmed by civilians is irrelevant with respect to the legal status of the UMS. 
2. Control and deployment of UMS can include either direct control or the setting of mission conditions, objectives or parameters.

\section{Rule 53}

The employment of UMS for the purposes of attack is subject to the applicable principles and rules of LOAC, in particular, distinction, proportionality and the obligation to take all feasible precautions.

\section{Commentary}

1. Whereas many UMS are used for ISR or oceanography, some are designed for combat purposes, such as those employed for ASW, MCM or mine-laying. If and to the extent UMS are employed for the purposes of attack, they qualify as means of warfare, ${ }^{7}$ and their employment is subject to weapons law and targeting law.

\section{Rule 54}

(a) UMS may be made the object of attack if they qualify as lawful targets.

(b) Enemy military UMS under Rule 52 are:

i. military objectives by nature; and

ii. subject to the concept of booty of war.

\section{Commentary}

1. Subparagraph (a) applies also to neutral UMS if they qualify as military objectives. See Rule 55.

2. This Rule reflects the customary definition of military objectives. ${ }^{8}$ Like enemy warships, military UMS make an effective contribution to the enemy's military action by nature. Therefore, their destruction, capture or neutralization will regularly offer a definite military advantage. Non-military UMS of enemy character qualify as military objectives only if they make an effective contribution to the enemy's military action by use, purpose or location and their total or partial destruction or neutralization, in the circumstances ruling at the time, offers a definite military advantage.

3. If captured, enemy warships and military UMS constitute "booty of war" and, therefore, title to them passes without the need for prize proceedings.

\section{Rule 55}

Neutral UMS may not be attacked or captured, unless they qualify as lawful targets.

\footnotetext{
${ }^{7}$ As defined in AMW Manual, see chapter "Section I: Outer Space", fn. 1, Rule 1 (t).

${ }^{8}$ San Remo Manual, see chapter "Section I: Outer Space”, fn. 29, para 40. See also Rule 77.
} 


\section{Commentary}

1) As in the case of neutral merchant vessels, neutral civilian UMS are liable to attack if they make an effective contribution to the enemy's military action by use, purpose or location and their total or partial destruction, capture or neutralization, in the circumstances ruling at the time, offers a definite military advantage. 9

2) It needs to be emphasized that capture under this Rule must be distinguished from capture as prize. The latter is not limited to vessels or UMS qualifying as lawful targets.

3) Therefore, neutral civilian UMS may become military objectives if they:

a. Engage in belligerent acts on behalf of the enemy;

b. Are incorporated into or assist the enemy's intelligence system;

c. Act as auxiliaries to the enemy's armed forces; or

d. Otherwise make an effective contribution to the enemy's military action.

4) It needs to be stressed that, at present, the capture of neutral civilian UMS seems likely to occur only in very exceptional situations. It seems unlikely that UMS would be used for the transport of cargo that could constitute contraband. Nevertheless, it may be imprudent to predict with confidence how technologies will be employed in the future.

5) Should neutral civilian UMS carry cargo qualifying as contraband, they are liable to capture. ${ }^{10}$ The contraband cargo will be liable to condemnation in prize proceedings. If the contraband, reckoned either by value, weight, volume, or freight, forms more than one-half of the cargo, the UMS itself may be condemned by a prize court. $^{11}$

\section{Rule 56}

Enemy UMS are not liable to capture, if they are used exclusively for non-military scientific purposes.

\section{Commentary}

1. Like enemy merchant vessels, UMS are liable to capture outside neutral waters. ${ }^{12}$ According to Article 4 of the 1907 Hague Convention (XI) ${ }^{13}$ and customary

\footnotetext{
${ }^{9}$ San Remo Manual, ibid, para 67.

${ }^{10}$ Declaration concerning the Laws of Naval War (London Declaration) (1909), The Laws of Armed Conflict, page 845, Article 37; San Remo Manual, see chapter "Section I: Outer Space", fn. 29, para 146(a).

${ }^{11} 1909$ London Declaration, see fn. 10, Article 40.

${ }^{12}$ San Remo Manual, see chapter "Section I: Outer Space", fn. 29, paras $112 \mathrm{ff}$.

${ }^{13}$ Convention (XI) Relative to Certain Restrictions with Regard to the Exercise of the Right of Capture in Naval War, (1907), The Laws of Armed Conflicts, page 819.
} 
international law, ${ }^{14}$ "vessels charged with scientific missions are [...] exempt from capture".

2. However, they are exempt from capture only if they:

a. Are innocently employed in their normal role;

b. Do not commit acts harmful to the enemy; and

c. Do not intentionally hamper the movement of enemy naval forces.

\section{Rule 57}

In so far as the use of neutral waters and ports is concerned, belligerent UMS are subject to the same rules as manned belligerent warships. Accordingly:

(a) Hostile actions by belligerent UMS are prohibited.

\section{Commentary}

1. The prohibition of hostile actions in neutral waters has been acknowledged in Article 2 of the 1907 Hague Convention (XIII) ${ }^{15}$ and is customary in nature. ${ }^{16}$ Accordingly, it also applies to belligerent UMS.

2. Neutral waters consist of the internal waters, territorial sea, and, where applicable, the archipelagic waters, of Neutral States. ${ }^{17}$

3. Hostile actions include, inter alia:

a. Attack of objects and persons located in, on or over neutral waters or territory; or

b. Laying of mines.

(b) Belligerent UMS may not use neutral waters as a base of operations or as a sanctuary.

\section{Commentary}

1. This prohibition is based on Article 5 of the 1907 Hague Convention (XIII) and customary international law. ${ }^{18}$

(c) Subject to the 24-hour rule, belligerent UMS have the right of stay in neutral ports or of innocent passage in neutral waters, unless the neutral coastal State has, on a non-discriminatory basis, conditioned, restricted or prohibited such stay or passage.

\footnotetext{
${ }^{14}$ San Remo Manual, see chapter "Section I: Outer Space", fn. 29, para. 136 (e).

${ }^{15} 1907$ Hague Convention (XIII) on Neutrality in Naval War, see chapter "Section I: Outer Space", fn. 23 .

${ }^{16}$ San Remo Manual, see chapter "Section I: Outer Space", fn. 29, para 15.

${ }^{17}$ San Remo Manual, ibid, para 14.

${ }^{18}$ San Remo Manual, ibid, paras 16 (b) and 17.
} 


\section{Commentary}

1. In times of armed conflict, UMS continue to enjoy navigational rights, including innocent passage, transit passage, and, where applicable, archipelagic sea lanes passage, in neutral waters. However, a belligerent UMS may not extend the duration of its passage through neutral waters for longer than 24 hours unless this is unavoidable on account of damage or the stress of weather. ${ }^{19}$ The 24 hours' limitation does not apply to transit passage or to archipelagic sea lanes passage.

2. A Neutral State may, on a non-discriminatory basis, condition, restrict, or prohibit the entrance to or passage through its territorial sea by Belligerent State vessels, including UMS operated for non-commercial Government purposes. ${ }^{20}$

\section{Rule 58}

A Neutral State may not suspend or otherwise hamper the rights of belligerent UMS as regards transit passage in international straits and passage through archipelagic sea lanes.

\section{Commentary}

1. The concepts of transit passage and of archipelagic sea lanes passage have been recognized in Articles 38 and 53 of UNCLOS.

2. In view of the importance of these passage rights, they have matured into customary international law, which applies in times of peace as well as of international armed conflict. ${ }^{21}$

\section{Rule 59}

(a) In the Exclusive Economic Zone or on the continental shelf of Neutral States, UMS must be employed with due regard for the rights and duties of the coastal State.

\section{Commentary}

1. In an international armed conflict, Belligerent States are not barred from the exercise of belligerent rights in the EEZ or on the continental shelf of Neutral States. However, Neutral States continue to enjoy functionally limited sovereign rights. Accordingly, when conducting hostile actions within the EEZ or on the continental shelf of Neutral States, belligerents shall, in addition to observing the basic principles and rules of the law of naval warfare, have due regard for the rights and duties of the coastal State, inter alia, for the exploration and exploita-

\footnotetext{
${ }^{19}$ San Remo Manual, ibid, para 21.

${ }^{20}$ San Remo Manual, ibid, para 19.

${ }^{21}$ San Remo Manual, ibid, para 29.
} 
tion of the economic resources of the EEZ and the continental shelf and the protection and preservation of the marine environment. ${ }^{22}$

(b) Hostile actions on the high seas involving the use of UMS must be conducted with due regard for the high seas freedoms of Neutral States and for the exploration and exploitation of the "Area" under the 1982 Law of the Sea Convention.

\section{Commentary}

1. Although Belligerent States may exercise belligerent rights in the high seas, the vessels of Neutral States continue to enjoy high seas freedoms. Moreover, the seabed and subfloor beyond the limits of national jurisdiction-the "Area"23 enjoys a special legal status that cannot be ignored. Accordingly, Belligerent States are obliged to pay due regard to those lawful uses of the high seas and of the "Area".

(c) The obligation of due regard is without prejudice to recognized force protection measures, such as warning zones or defence bubbles.

\section{Commentary}

1. Under customary international law, defence bubbles and warning zones as well as the control of the immediate vicinity of naval and aerial operations are recognized measures of force protection that apply in times of peace and of international armed conflict. $^{24}$ They are lawful provided that they do not unduly impede the exercise of the freedoms of the high seas by neutral vessels, and that any uses of force to protect activities from interference are necessary and proportionate.

2. Belligerent States continue to enjoy the right to take all necessary measures of force protection. However, efforts should be made to ensure that the implementation of any warning zone or a defence bubble does not conflict with the requirements of a safety zone established by the neutral coastal State around artificial islands, installations or structures.

\section{Rule 60}

In sea areas beyond the territorial sea of any State, UMS operated by Neutral States for exclusively non-commercial governmental purposes must be respected.

\footnotetext{
${ }^{22}$ San Remo Manual, ibid, para 34.

${ }^{23}$ UNCLOS, see fn. 3, Article 1(1).

${ }^{24}$ San Remo Manual, see chapter "Section I: Outer Space", fn. 29, para 108; AMW Manual, see chapter "Section I: Outer Space", fn. 1, Rule 106.
} 


\section{Commentary}

1. UMS operated by Neutral States for exclusively non-commercial governmental purposes enjoy sovereign immunity. They may neither be attacked, nor captured, visited, searched or otherwise interfered with.

2. This Rule applies in sea areas beyond the territorial sea of Neutral States. Of course, within neutral waters, UMS still enjoy sovereign immunity consistent with international law, and Belligerent States are obliged to refrain from any exercise of belligerent rights.

Open Access This chapter is licensed under the terms of the Creative Commons Attribution 4.0 International License (http://creativecommons.org/licenses/by/4.0/), which permits use, sharing, adaptation, distribution and reproduction in any medium or format, as long as you give appropriate credit to the original author(s) and the source, provide a link to the Creative Commons licence and indicate if changes were made.

The images or other third party material in this chapter are included in the chapter's Creative Commons licence, unless indicated otherwise in a credit line to the material. If material is not included in the chapter's Creative Commons licence and your intended use is not permitted by statutory regulation or exceeds the permitted use, you will need to obtain permission directly from the copyright holder. 